Relations industrielles

Industrial Relations

\title{
Bamber, Greg J., and Russell D. Lansbury, ed., International and Comparative Industrial Relations : A Study of Industrialised Market Economies
}

\section{Hans Slomp}

Volume 49, numéro 3, 1994

URI : https://id.erudit.org/iderudit/050962ar

DOI : https://doi.org/10.7202/050962ar

Aller au sommaire du numéro

Éditeur(s)

Département des relations industrielles de l'Université Laval

ISSN

0034-379X (imprimé)

1703-8138 (numérique)

Découvrir la revue

Citer ce compte rendu

Slomp, H. (1994). Compte rendu de [Bamber, Greg J., and Russell D. Lansbury, ed., International and Comparative Industrial Relations : A Study of Industrialised Market Economies]. Relations industrielles / Industrial Relations, 49(3), 604-606. https://doi.org/10.7202/050962ar

Tous droits réservés @ Département des relations industrielles de l'Université Laval, 1994
Ce document est protégé par la loi sur le droit d'auteur. L’utilisation des services d'Érudit (y compris la reproduction) est assujettie à sa politique d'utilisation que vous pouvez consulter en ligne.

https://apropos.erudit.org/fr/usagers/politique-dutilisation/ 


\section{RECENSIONS BOOK REVIEWS}

International and Comparative Industrial Relations : A Study of Industrialised Market Economies, by Greg J. BAMBER and Russell D. LANSBURY (ed.), second edition, London, Routledge, 1993, 374 p., ISBN 0-415-10360-6.

This is the second edition of a book which does not need an introduction, since the first edition, published in 1987, has been widely used as a text in comparative labor courses. For those who have come of age since then : Like the first edition it contains a number of country-chapters, as well as a few more general and comparative chapters. The country chapters discuss the seven largest industrialized market economies (the G-7 group, consisting of the United States and Canada, Japan, Germany, Great Britain, France and Italy), as well as Australia and Sweden. Major changes with the first edition are a new preface, by Thomas A. Kochan, replacing the one by Roger Blanpain, and a new concluding chapter, by Oliver Clarke.

Because of the time lag since the first edition was published six years ago, I will discuss the whole book rather than the changes in the new edition. The review focuses on three points. First, the editors' job in presenting these particular chapters and in providing a common structure for the chapters. Second, the quality of the country chapters, in other words, the authors' job, and third, the editors' introducing and concluding chapters.

As to the first point, the editors have been highly successful in enforcing a general structure. All country chapters start with a short historical note, followed by a short note on economic and political conditjons, the main actors, the processes of bargaining, conflict, and worker participation, and a discussion of current and future issues. One of the few exceptions is the absence of a section on current and future issues in Italy. The framework, of course, is a traditional one, well-tried in similar surveys. It allows the authors ample room for dwelling longer on national peculiarities without having to give up the comparative aim. It also leads to the prevalence of description over analysis, common to most nation surveys. A disadvantage of that presentation is that it shows a lot of country-specific developments, without a more analytical discussion. In the third edition, which I am sure will come, why not add a country-specific section to each chapter, focusing on the preconditions of national peculiarities, like Australian bargaining-bymeans-of-arbitration, German industrial unionism, Japanese enterprise unionism, and Swedish national bargaining? There is some focus on these topics, but a more systematic effort to single them out for separate treatment would have added to the analytical level of the survey, and made the countries more come to life. The French chapter contains such a section explaining the low union density, but four out of the five causes listed there, like the absence of closed shops and of union provided benefits, apply to most European unions, with much higher unionization rates. Indeed, this shows the problems involved in such a more analytical discussion, but it might be worth trying. 
Most of the country chapters are well written and packed with information, ranging from the rise of the early unions to the latest challenges to employers and unions, like new technologies and Human Resources Management. The short Canadian chapter (by Mark Thomson) is even a bit overpacked, since it tries to summarize the normal 25 pages in 15 pages. It would be easy to list points that deserve more attention in such short surveys, but deficiencies are rare. The chapters stand as representative introductions to the national systems of industrial relations. My own first priority of additions would be a more detailed discussion of the composition, the recruitment of new members, and the functioning of the Australian Industrial Relations Commission, in order to allow a better assessment of the difference between bargaining and arbitration in that country. The next priority would be a discussion of union-enterprise conflict in Japan. The 'Western' negative view of enterprise unionism, to which the author, Yasuo Kuwahara, refers, will be reinforced rather than rebuked by the claim that Japanese companies are akin to quasiemployee-managed firms, 'where the interests of employees are well represented' (p. 232).

Although the conclusions have been written by Oliver Clarke, we might well treat that chapter as belonging to the editorial part of the book, together with the introduction and the Appendix. The first chapter, by the editors, offers a short introduction to theoretical approaches, from Dunlop to Kochan, including a discussion on convergence and divergence, resulting in an adaptation of an analytical framework by Kochan et al. Although it can stand in its own right, this chapter does not really serve the function of an introduction. The framework is hardly used in the country chapters, which follow a traditional, but effective, order. Moreover, the part on convergence and divergence mentions comparative research, for instance on worker participation, but the country chapters do not refer to it and it is not recaptured at the end of the book. That is not to say that the concluding chapter, by Oliver Clarke, is not a good one. It draws a number of general lines from the nation chapters, for instance about shifts in bargaining and the position of government and discusses the role of the ILO. Appendix is really too modest a name for the chapter on 'Employment, economics, and industrial relations: Comparative Statistics. This chapter, by Greg J. Bamber and Gillian Whitehouse, offers more than statistics. It also points to the problems of comparing statistical data and it reviews explanations of national differences.

This is a fine comparative survey, and especially due to the new concluding chapter it is an even better one than the first edition. The points raised here do not affect my appreciation of this book. There is one point which does, however: The arbitrary comparisons, made in all chapters. Comparison is at the heart of this book, but it is done in a very unsystematic way: With the rest of the group of countries discussed, with all OECD-countries, with the English-speaking countries, with just one foreign country, including nations outside the scope of the book, like Austria, or with a select group of nations. The table on strike frequency shows that Greece is most strike prone, and Switzerland least. Greek and Swiss readers will certainly be delighted with their nations' position, but it does not clarify much. Neither does the remark, in several of the country chapters, that industrialization was later than in Great Britain. One remark, in the British chapter, will do. 
Recently, a number of country-by-country comparisons have been published, in particular on Europe, like the Baglioni/Crouch and the Ferner/Hyman volumes. It is tempting to make a comparison, despite the fact that this book only covers five European countries, in addition to four other nations. I would say that this book is more of a unity than any of the other two, but that the comparative chapters in the other volumes offer more of a real comparison. While the Baglioni/Crouch volume is too diverse to serve as an introduction, the Ferner/Hyman survey is a more analytical one, up to the point of taking for granted a lot of knowledge about some of the countries covered there. I agree with Streeck's conclusion, cited on the (beautiful) cover, that this is 'a good first introduction to comparative industrial relations'. It may not be a better introduction than the other volumes, but it definitely is the best first introduction.

Hans Slomp

Cornell University

Grand Designs: The Impact of Corporate Strategies on Workers, Unions, and Communities, by Charles Craypo and Bruce Nissen, Ithaca, NY, ILR Press, 1993, 285 p., ISBN 0-87546-309-6 (acid-free paper) and ISBN 0-87546-310-X (pbk).

Publication of The Transformation of U.S. Industrial Relations focused scholars on the role of corporate strategy in guiding relations between managers and workers. Grand Designs furthers our understanding of corporate approaches through detailed analyses on how they affect workers and communities and how those affected have responded to corporation actions. Through nine case studies, the book moves from situations in which companies imposed their strategies on workers without effective opposition to those in which labor-community coalitions were able to compel firms to negotiate through use of national laws and political pressure. The employee-community perspective and the detail of the studies provide useful balance to a literature which has tended toward abstraction and a management oriented outlook.

Several themes run through these studies of plant closing and union decertification in the heavily industrialized Midwest of the United States. First, it appears that corporate strategies are less the inevitable consequence of changing markets than the outcome of how firms have chosen to respond to these pressures. The low wage non-union strategy is only one of several possible approaches. Second, labor concessions alone are unlikely to change corporate managements approach to the problem. Similarly, traditional business oriented community development strategies of providing subsidies and tax relief to companies are also unlikely to alter corporate strategies. Finally, development of labor-community coalitions and the judicious use of political and legal leverage can provide workers and communities a means of opposing the strategies which lead to labor and community decline.

The first and second themes are apparent in most of the case studies. Charles Jeszek's study of the decline of tire manufacturing in Akron is particularly illustrative. Akron's decline was apparently due to of the failure of the American firms to make timely investments in radial tire technology and a decision to build new plants 